\title{
Effects of Calotropis procera (Ait.) R.Br. leaves on the Germination and Early Growth of Soybeans (Glycine max. (L) Merrill).
}

\author{
Ayeni, M.J. ${ }^{1}$ and Akinyede, O.A. ${ }^{2}$ \\ ${ }^{1}$ (Department of Plant Science, Ekiti State University, Ado-Ekiti, Nigeria.) \\ ${ }^{2}$ (Department of Plant Science, Ekiti State University, Ado-Ekiti, Nigeria.)
}

\begin{abstract}
The study examined the effects of Calotropis procera powdered extracts on the germination and growth of soybeans (Glycine max L. merrill), an important crop in Nigeria. The result showed that C. procera leachates inhibited the germination and growth of soybeans. The degree of inhibition was concentration dependent as the inhibition increased with increase in the concentration of the extracts. Statistical analysis( ANOVA, $P=0.05$ ) revealed that there were significant differences in in the coefficient of velocity ( COV), plumule length, number of leaves at harvest, fresh weights of roots and shoots and dry weights of roots compared to the control experiments. No significant difference was observed in the percentage germination and shoot dry weights of soybeans treated seeds compared to control experiments.
\end{abstract}

Keywords: Calotropis procera, Allelopathy, Inhibition, Allelochemicals

\section{Introduction}

Weeds are widely known to have caused considerable reductions in the yield of agricultural crops. Losses to weeds were estimated to be up to $70 \%$ of the yields (Shad, 1986). Chandler (1986) and Putnam (1985) estimated that crop losses to weeds were up to \$9-10 billion annually in USA alone. Apart from weeds competing with crops, chemical substances called allelochemical are released from them which can either have inhibitory or stimulatory effects on crops. The threat of the weeds had forced farmers to use pesticides as a possible control measure to control weeds. Such interference is referred to allelopathy.

According to Koul and Singh (1989), allelopathy is the phenomenon whereby the plant (donor) has a detrimental effect on another (receptor) plant. Allelopathy was first coined by Molish 1937 to include both inhibitory (harmful) and beneficial (stimulatory) effects of plants on each other (Rice, 1984 and Willis, 1985). Also, Weir et al. (2004) described allelopathy as any direct or indirect effect of plant chemical compounds on another plants or microbes.

The inhibitory substances (allelochemicals) are released to the environment where they affect the growth and development of neighbouring plants. The allelochemicals are found in plant parts such as leaves, flowers, roots, fruits, stem, rhizomes and seeds( Sisodia and Siddiqui, 2010) from where they are released into the soil through volatilization, root exudation, leaching and decomposition of plant residues in both natural and agricultural systems( Ferrugson and Rathinasabapathi, 2003., Rice, 1984., Rizvi and Rizvi, 1992., Sisodia and Siddiqui, 2010).

The most cited effects of allelopathy on plants include reduced seed germination and seed growth. Other known physiological targets sites for some allelochemicals include cell division, pollen germination, nutrient uptake, photosynthesis and specific enzyme action (El- Khatib et al., 2004, Jamali, et al., 2006, Kim and Lee, 2011 and Mansour, 2013). Allelopathy had been studied by various researchers such as Aleksieva and Serafimov (2008), Kadioglu et.al. (2005), Kayode and Ayeni, (2010), Ayeni and Kayode, (2012, 2013).

Calotropis procera Dence (Ait) is a member of the family Asclepidiaceae. It is an evergreen poisonous shrub. It grows commonly around farms, agricultural areas and in the sandy warm parts. The plant grows naturally and widely spread in different areas. It is commonly abundant in Bauchi, Borno, Kano, Kaduna and most parts of Northern Nigeria (Sofowora, 1984, Adams, 1995 and Sharma et al., 1997.).C. procera has the potential of dominating its natural habitat because it has allelochemical compounds that enable it to compete with other species as it inhibit the growth and production of crops (Al-Zahrani, and Al- Robai, 2007).The study aimed at evaluating the allelopathic effects of $\mathrm{C}$. procera leaves powdered extracts on the germination and growth of Soybeans, an agricultural crop in Nigeria.

\section{Materials And Methods}

Screen house experiment was conducted in the Department of Plant Science, Ekiti State University, Ado- Ekiti, Nigeria between January and May 2009 to examine the effects of C. procera leaves powdered extracts on the germination and growth of soybeans. Humus soil, to a depth of $10 \mathrm{~cm}$ depth, was collected from a 
regenerating forest very close to plant science laboratory. The soil was oven dried at $100^{\circ} \mathrm{C}$ for 45 minutes to destroy the existence of buried seeds in the soil.

Calotropis procera leaves were collected from Egbe in Kogi State, Nigeria. The leaves were air- dried for three weeks, pounded with pestle and mortal and later blended into powder with the aid of a blender. Soybean seeds were obtained from Agricultural Development Project (ADP) centre, Ikole - Ekiti. Proper seed selection was carried out before usage.

Portions of $10 \mathrm{~g}, 20 \mathrm{~g}, 30 \mathrm{~g}$ and $40 \mathrm{~g}$ were measured out from the powdered leaves and were replicated four times. 990g of sterilized soil sample were also measured withElectronic Top Loading Digital balance; G\& G model JJ 300YChina and put inside planting pots. Each portion of measured powder was mixed intermittently with the soil samples. Control experiment was set up with pots without powdered leaves and also replicated four times.

Five seeds of soybeans were planted in each planting pots and were moistened daily in the morning with $60 \mathrm{ml}$ of water. The seeds were considered germinated upon plumule emergence. The stem heights were measured for six weeks. The parameters assessed were seed germination, plumule lengths, number of leaves, fresh and dry weights of roots and shoots.

The speed of germination known as coefficient of velocity (COV) was calculated according to Kayode (2000) as:

$\mathrm{COV}=\underline{\mathrm{A}_{1}+\mathrm{A}_{2}+\mathrm{A} 3 \ldots \ldots \ldots \mathrm{A}_{\mathrm{n}} \mathrm{T}_{\mathrm{n}}}$
$\mathrm{A}_{1} \mathrm{~T}_{1}+\mathrm{A}_{2} \mathrm{~T}_{2}+\mathrm{A}_{3} \mathrm{~T}_{3}+\mathrm{A}_{\mathrm{n}} \mathrm{T}_{\mathrm{n}}$$\quad$ x $\quad 100$

Where:

$\mathrm{A}=$ number of seedlings that emerge at a particular number of days

$\mathrm{T}=$ number of days involved.

At three weeks after planting, the soybeans plants were thinned to one plant per pot leaving the most vigorous and healthier plant and the weekly height measurements were recorded for six weeks.

The plants were carefully uprooted and washed thoroughly before it was later separated into roots and shoots. The fresh weights of the roots and shoots were weighed using Electronic Top Loading Digital balance; G\& G model JJ 300YChina.They were properly tagged and kept in the herbarium of Plant Science Department, Ekiti State University for three weeks to obtain the dry weights. The means from the parameters evaluated were subjected to one way analysis of variance (ANOVA) using SPSS Version 15 (2009) computer software. Duncan Multiple Range Test (DMRT) at 5\% probability level was used as a follow up test to separate the means.

\section{Seed germination}

\section{Results And Discussion}

The effects of $\mathrm{C}$. procera leaves extracts on the germination and coefficient of velocity (COV), also known as speed of germination, of soybeans was shown in Table 1. The germination of seeds and COV were affected by the C. procera leaves extract. The germination \% of seeds in the control was $95 \%$, those of 10, 20, 30 and $40 \mathrm{~g}$ were $85 \%, 80 \%, 90 \%$ and $90 \%$ respectively. COV in the control was 56.36 which decreased to 23.0 in $40 \mathrm{~g}$ concentration. It was observed that COV of soybeans decreased with increase in the concentration of the extracts showing that the effects of the C. procera leaf powder extracts were concentration dependent. The study agreed with the earlier work of Al- Zahrani and Al- Robai (2007) who found that the seed germination of some plants were affected by C. procera leaves extracts as the germination percentage were delayed at the higher concentration. The final germination percentage was decreased by the increasing leaf extract concentration. Also, Ahmad (2012) observed similar inhibition in the germination of Cicer arietenum by the increasing concentrations of aqueous extracts of Vicia species. Oyun (2006) also noted that maize seed germination was inhibited by G. sepium and A. auriculifomis as the concentration of the aqueous extracts increases. Seerjana et al. (2007) reported that the leaf aqueous extracts of Parthenium hysterophorus exhibited significant effects on seed germination on seedling growth of all test species. Oluwole et. al. (2013) noted that germination percentages of Zea mays seeds were significantly decreased as the concentration of the different solvent extracts of C. nocturnum leaf increases. Tefera (2002) and Siddiqui et. al. (2009) had earlier reported that leaf extract had the strongest allelopathic effects on seed germination. This might be responsible for the inhibition exhibited by $\mathrm{C}$. procera leaves on soybean germination as shown in this study. 
Statistical analysis (ANOVA, $\mathrm{P}=0.05$ ) revealed that there was no significant difference in the germination percentage of soybeans compared to the control experiment. However, the speed of germination showed significant different compared to control experiment.

Table1.Effects of C. procera leaves on the germination percentage and Speed of germination (COV) of soybean seeds.

\begin{tabular}{lll}
\hline Treatment $(\mathrm{g})$ & Germination $\%$ & Speed of germination $(\mathrm{COV})$ \\
\hline 0 & $95 \mathrm{a}$ & $56.36 \mathrm{a}$ \\
10 & $85 \mathrm{a}$ & $44.58 \mathrm{~b}$ \\
20 & $80 \mathrm{a}$ & $41.35 \mathrm{~b}$ \\
30 & $90 \mathrm{a}$ & $33.92 \mathrm{c}$ \\
40 & $90 \mathrm{a}$ & $23.00 \mathrm{~d}$ \\
\hline
\end{tabular}

Means followed by the same letter within column are not significantly different at $(\mathrm{P}=0.05)$

\section{Plumule Length}

The effects of $C$. procera powdered extracts on the number of leaves at harvest and plumule lengths were shown in Table 2. The mean number of leaves of soybeans was 18.00 in the control, those of $10 \mathrm{~g}, 20 \mathrm{~g}, 30 \mathrm{~g}$ and $40 \mathrm{~g}$ were $15.25,14.25,13.75$ and $10.25 \mathrm{~g}$ respectively. This tends to suggest that the effects of $C$. procera leaves extracts were concentration dependent as the number of leaves reduced with increase in the concentration of the extracts.

For the plumule lengths, control experiment had $57.46 \mathrm{~cm}$ in the control which reduced to $32.95 \mathrm{~cm}$ in $40 \mathrm{~g}$ concentration. The effects of the extracts on the plumule length also decreased with increased extract concentration. The result agreed with the findings of Jadhar and Goyanar (1992) who noted that the \% germination, plumule length and radicle length of rice and cowpea were decreased with increase in the concentration of Acacia auriciliformis leaf leachates. Rahman(1995) noted the effects of aqueous extracts of maize inflorescence stem and leaves of Parthnium hysterophorus L. on the growth of radicle and plumule lengths of Cassia sophera $\mathrm{L}$.

Kayode and Adanlawo (1997) revealed that the extracts from leaves of G. sepium had inhibitory effects on the growth of radicle and plumule of cowpea (Vigna unguiculata).

Statistical analyses (ANOVA, $\mathrm{P}=0.05$ ) revealed that both the number of leaves and plumule lengths of soybeans showed significant differences to the control experiments.

Table 2.Effects of $C$. procera leaves on the number of leaves and plumule length of soybean.

\begin{tabular}{lll}
\hline Treatment $(\mathrm{g})$ & Number of leaves & Plumule length \\
\hline 0 & $18.00 \mathrm{a}$ & $57.46 \mathrm{a}$ \\
10 & $15.25 \mathrm{~b}$ & $53.62 \mathrm{~b}$ \\
20 & $14.25 \mathrm{~b}$ & $47.29 \mathrm{c}$ \\
30 & $13.75 \mathrm{~b}$ & $43.25 \mathrm{~d}$ \\
40 & $10.25 \mathrm{c}$ & $32.95 \mathrm{e}$ \\
\hline
\end{tabular}

Means followed by the same letter within column are not significantly different at $(\mathrm{P}=0.05)$

\section{Biomass production}

The effects of C. procera powdered leaf extracts on the fresh and dry weights of shoots and roots of soybeans are shown in Table 3. The extracts inhibited both the fresh and dry roots and shoots of soybeans. The fresh root weight was $0.51 \mathrm{~g}$ in the control experiment. Those of $10 \mathrm{~g}, 20 \mathrm{~g}, 30 \mathrm{~g}$ and $40 \mathrm{~g}$ were $0.39 \mathrm{~g}, 0.33 \mathrm{~g}, 0.25 \mathrm{~g}$ and $0.22 \mathrm{~g}$ respectively. The fresh shoot weight has $3.78 \mathrm{~g}$ which decreased to $1.54 \mathrm{~g}$ in $40 \mathrm{~g}$ concentration. Likewise, dry root weight had $0.11 \mathrm{~g}$ in the control which decreased to $0.05 \mathrm{~g}$. Also, dry shoot weight of soybeans had $0.14 \mathrm{~g}$ in the control experiment which decreased to $0.10 \mathrm{~g}$ in $40 \mathrm{~g}$ concentration. The fresh and dry shoot weights reduced with increase in the concentration of the extracts.

Statistical analysis revealed that significant differences were observed in the fresh root and shoot weights as well as the dry root weights compared to the control experiments. However, there was no significant difference in the dry shoot weights compared to the control experiment.

Previous researchers such as Yarnia (2009) noted that sorghum extract treatments decreased the dry weight of Amaranthus which resulted to decreased seedling growth. Also, Nasira and Moinuddin (2009) noted that fresh and dry weights of maize were affected only at higher concentration of used weed material in the soil. Similarly Rose et al. (1984) found that due to the allelopathic potentiality, some soybeans cultivars reduced $46 \%$ and $65 \%$ of dry weights of velvet beans(foxtail millet) respectively. Oyun (2006) also observed significant decrease in the shoot fresh weight, root fresh weight, shoot dry weight and shoot dry weight of maize with increasing concentrations of Gliricidia sepium and Acacia auriculiformis leachates. 
Table 3.Effects of $C$. procera leaves on the fresh and dry root and shoot weighs of soybean.

\begin{tabular}{lllll}
\hline Treatment $(\mathrm{g})$ & FRW & FSW & DRW & \\
\hline 0 & $0.51 \mathrm{a}$ & $3.78 \mathrm{a}$ & $0.11 \mathrm{a}$ & \\
10 & $0.39 \mathrm{~b}$ & $3.23 \mathrm{ab}$ & $0.09 \mathrm{~b}$ & $0.14 \mathrm{a}$ \\
20 & $0.33 \mathrm{~b}$ & $2.66 \mathrm{bc}$ & $0.08 \mathrm{~cd}$ & $0.12 \mathrm{a}$ \\
30 & $0.25 \mathrm{c}$ & $1.98 \mathrm{~cd}$ & $0.07 \mathrm{~d}$ & $0.10 \mathrm{a}$ \\
40 & $0.22 \mathrm{c}$ & $1.54 \mathrm{~d}$ & $0.05 \mathrm{c}$ & $0.09 \mathrm{a}$ \\
\hline
\end{tabular}

Means followed by the same letter within column are not significantly different at $(\mathrm{P}=0.05)$

*FRW= Fresh Root Weight, FSH= Fresh Shoot Weight, DRW= Dry Root Weight

DSW = Dry Shoot Weight

\section{Conclusion}

The inhibitory effects exercised by the leaves of Calotropis procera on the parameters studied might be as a result of allelochemicals such as calotropin present in the leaves of C.procera (Daubenmine, 1974). Kuriachen and Dave (1989) also reported that the latex of Calotropis procera contains several alkaloids such as Calotropin, Catotoxin, Calcilin, Gigantin which are caustic and considered poisonous in nature which might be responsible for the inhibitory effects shown on the germination and growth of soybeans in this study.

\section{References}

[1]. Ahmed, K.K.,Rana, A.C. and Dixit, V.K .2005.Calotropis Species (Asclepidaceae)-A comprehensive review. Pharma. Mag., 1(2): $48-51$

[2]. Ahmad, M. 2012. Evaluation of allelopathic potential of Weedy Species of Vicia on Gram (Cicer arietenum). International Journal of Advance Research in Science and Engineering. 1(1): 1-12.

[3]. Aleksieva, A. and Serafimov, P. 2008. A study of allelopathic effect of Amaranthus retroflexus (L.) and Solanum nigrum(L.) in different soybeans genotypes. Herbologia .9(2): 47-58.

[4] Al-Zahrani, H. S. and Al- Robai, S. A. Allelopathic effects of Calotropis procera leaves extracts on seeds germination of some plants. JKAU Sci. 9: 115-126.

[5]. Ayeni, M.J. and Kayode, J.2012. Allelopathic Potential of Some Crop Residues on the Germination and Growth of Soybean (Glycine max L.)Merrill. Journal of Agricultural Science and Technology B. 2(10): 1057-1061.

[6]. Ayeni, M.J.and Kayode, J. 2013. Allelopathic effects of Sorghum stem and Maize Inflorescence Residues on the Germination and Growth of Okra (Abelmoschus esculentus L.).Journal of Food, Agriculture and Environment. 11(1): 320-323.

[7]. Chandler, M. 1985. Economics of weed control in crops. Pp.20. In: A Thompson (ed) ACS.Symposiumseries,No 268. The Chemistry of Allelopathic Biochemical InteractionAmongPlants.American Chemical Society.

[8]. Daubenmire, R.F.1974. Plants and Environment, $3^{\text {rd }}$ edition.John Wiley and Sons, New York, USA. Pp. 54-70.

[9]. El- Khatib, A.A., Hegazy, A.K.and Gala, H.K. 2004. Does allelopathy have a role in the ecology of Chenopodium murale. Ann. Bot. Fennici. 41: 37-45.

[10]. Ferrugson, J.J. and Rathinasabapathi, B. 2003. Allelopathy: How plants suppress other plants. University of Florida. Institute of Food and Agriculture Sciences, UF/IFAS, Florida, USA.

[11]. Jadhar, B.B and. Gayanar, D.G.1992. Allelopathic effects of Acacia auriculiformis on germination of rice and cowpea. Ind. J. Plant Phys. 1: 86- 89.

[12]. Kadioglu, I., Yanar, Y. and Asav, U. 2005.Allelopathic effects of weed extracts against seed germination of some plants. Journal of Environmental Biology. 26(2):169- 173.

[14]. Jamali, A., Kouhila, M., Ait Mohamed, L. Jaouhari, J.T., Idlimam, A.andAbdenouri, N. 2006. Sorption isotherms of Chenopodium ambrosiodes leaves at three temperatures. Journal of Food Engineering. 72(1): 77-84.

[15]. Kayode. J. and Adanlawo, I.G. 1997. Allelopathic effects of aqueous extracts of Euphorbia heterophylla on radicle and plumule growth of cowpea (Vigna unguiculata) Walp. Bioscience Research Communications (10): 23-26.

[16]. Kayode, J. 2000. A study of seed stock in rainforest site in Ado Ekiti region, Nigeria .Bioscience Research Communication.12 (3): 325-339.

[17]. Kayode, J. and Ayeni, M .J. (2010). Allelopathic Potentials of Aqueous Extracts from Maize ((Zea mays) Roots and Pigeon pea (Cajanuscajan L.) Leaves on the Growth and Germination of Soybeans (Glycine max .L. .Merrill.).Bulletin of Pure and Applied Science.29B (No. 2): 63-68.

[18]. Kim, Y.O. and Lee, E.J. 2011.Comparision of phenolic compounds and the effects of Invasive and native species in East Asia: support for the novel weapons hypothesis. Ecol. Res. 26: 87-94.

[19]. Koul, V. K.and Singh, H. 1989.Evaluation of allelopathic influence of Leuceana leucocephala. Leucocephala Research Reports.10: 29-30.

[20]. Kuriachen, P.M and Dave, Y. 1989. Structural, developmental and histochemical studies in the collectors of Calotropis procera (Asclepiadaceae). J. Phytological Res. 2:7-14.

[21]. Mansour,M.M.F. 2013.Plasma membrane permeability as an indicator of salt tolerance in plants.Review, Biologia Plantarum. 57(1): $1-10$.

[22]. Nasira, J. and Moinuddin, A. 2009. Possible allelopathic effects of three different weeds on germination and growth of maize (Zea mays) cultivars. Pak..J. Bot. 41 (4):1677-1683.

[23]. Oluwole, E.O., Oladipupo, A.L.,Abimbola, A.O.and Oyedamola, O. 2013. Evaluating the allelopathic potential of Cestrumnocturnum leaf extracts on (Maize) Zea mays L. Canadian Journal on Computing in Mathematics, Natural Sciences, Engineering and Medicine.4(1): 65-68. 
[24]. Oyun, M.B.2006.Allelopathic potentials of Gliricidia sepium and Acacaia auriculiformis on the germination and seedling vigour of maize (Zea mays L.).American Journal of Agricultural and Biological Science. 1(3): 44-47.

[25]. Putnam,A.R. 1985. Weed allelopathy. Pp 131-135. In: S.O. Duke Ed.). Weed Physiology.Vol.1.Reproduction and Eco physiology.CRC Press

[26]. Quadia, P. 1999. Allelopathic effects of some obnoxious weeds on germination and seedling vigour of Lathyrus sativus. FABIS Newsletter, 42.

[27]. Rice, E.L. 1984.Allelopathy.Academic Press, New York, London, Rizvi, S.J.H., H. Haque, V.K. Singh and V. Rizvi, 1992. A discipline called Allelopathy: basic and applied aspects. Chapman and Hall, London, Pp. 9.

[28]. Rizvi, S. J. H., Haque, H., Singh, H.K. and Rizvi, V. 1992.A discipline CalledAllelopathy.Pp.1-10. In : Rizvi, S.J.H. (Eds.). Allelopathy; Basic and Applied Aspects Chapman and Hall Press, New York.

[29]. Seerjana, M., Bharat, B. S .and P. K. J. 2007. Allelopathic effects of aqueous extracts of leaves of Parthenium hysterophorus L. on seed germination and seedling growth of some cultivars and wild herbaceous species. Scientific World. 5: 33-39.

[30]. Shad, R. A., Hussain, M., Kham, R. U. and Ziauddin, M. 1986.Socio- economic aspects of losses in rice due to weeds. Potato Agric. Res. 7(4): 247-253.

[31]. Sofowora, A. 1984.Medical Plants and Traditional Medicine in Africa. John Wiley and Sons Limited, Ibadan. Pp.142-146.

[32]. Siddiqui, S., Meghvansi,K.,Yadav, K., Yadav, R., Wani, F.A. and Ahmad, A.2009. Efficacy of aqueous extracts of five arable trees on the seed germination of Pisum sativum L. var. VRP-6 and KPM-522. Bot. Res. Int., 2(1): 30-35.

[33]. Sisodia, S. and Siddiqui, M.B.2010.Allelopathic effect by aqueous extracts of different parts of Croton bonplandianum Baill.on some crop and weed plants. Journal of Agricultural Extension and Rural Development. 2(1): 22-28.

[34]. Tefera, T. 2002. Allelopathiv effects of Parthenium hysterophorus extracts on seed germination and seedling growth of Eragrostis tef (Zucc.)Trotter. Journalof Agronomy and Crop Science. 188(5): 306-310.

[35]. Weir, T.L., S-Park, W. and Vivanco, J.M.2004. Biochemical and Physiological mechanisms mediated by allelochemicals, Curr. Opin. Plant Biol. 7: 472-479.

[34]. Willis, R.J.1985. The historical bases of the concept of allelopathy. Journal of the history of Biology .18: 71-102.

[35]. Yarnia, M.; KhorshidiBenam, M.B.and Farajzadeh Memari Tabrizi, E. 2009.Allelopathic effect of sorghum extract on Amaranthus retroflexus seed Germination and growth. Journal of Food, Agriculture and Environment. 7(3 \& 4): 770-774. 